\title{
TRESPASSING CHILDREN: RESTATEMENT OF TORTS SECTION 339 IN CALIFORNIA
}

To the general rule that a landowner owes no duty to a trespasser an important exception is made where the trespasser is a child. ${ }^{1}$ This comment is designed to survey the child trespasser exception in California and consider the status of the California position in the light of Restatement of Torts, section 339 which has been stated to be "a new point of departure for the modern law." 2

Since the early case of Barrett v. Southern Pacific Company, ${ }^{3}$ California courts have recognized a right of recovery against occupiers of land for injuries sustained by trespassing children. The court expressed the broad concept of a landowner's responsibility in terms of general neghigence:

It is a maxim of the law that one must so use and enjoy his property as to interfere with the comfort and safety of others as hittle as possible, consistently with its proper use ... [T] [Tis principle, as a standard of conduct is of universal application, and the failure to observe it is, in respect to those who have a right to invoke its protection, a breach of duty, and, in a legal sense, constitutes negligence. 4

As a basis of liability this concept was criticized because it did not clearly enunciate whether a landowner owed any duty to a trespasser; therefore, the question of whether there was negligence, which is of course dependent upon the existence of a duty, should never have been reached..$^{5}$ This conceptual difficulty, however, was solved by analogy to a case where a landowner was held liable for luring his neighbors' dogs into traps baited with putrid meat. ${ }^{6} \mathrm{~A}$ similar allurement came to be required in the case of child trespassers; this together with proof of a dangerous condition constituted an "attractive nuisance." The allurement, if it was found, was treated as an implied invitation to children to meddle, thus making the child an invitee and eliminating any troublesome questions of the duty owed to trespassers. ${ }^{8}$ Although the language of allurement still occasionally manifects itself in the cases, ${ }^{9}$ it has been eliminated as a prerequisite for liability under California law. ${ }^{10}$

1 Doyle v. Pacific Elec. Ry., 6 Cal.2d 550, 59 P.2d 93 (1936).

2 PROSSER, TORTS 440 (2d ed. 1955).

391 Cal. 296, 27 Pac. 666 (1891). The Barrett case followed the leading "turntable" case of Sioux City \& Pac. R.R. v. Stout, 84 U.S. (17 Wall.) 657 (1873). For the subsequent history of this decision see 2 HARPER AND JAMES, ToRTS 1448 (1956).

4 Barrett v. Southern Pac. Co., 91 Cal. 296, 301-02, 27 Pac. 666, 667 (1891). The maxim is frequently found in its Latin form: sic utere tuo ut alienum non laedas.

6 Dobbins v. Missouri, K. \& T. Ry., 91 Tex. 60, 41 S.W. 62 (1897).

6 Townsend v. Wathen, 9 East 277, 103 Eng. Rep. 579 (1808). See Keffe v. Milwaukec \& St. Paul R.R., 21 Minn. 207 (1875), where the attraction to the child was likened to bait attracting a fish or putrid meat drawing a dog.

7 Cf., Gianinni v. Campodonico, $176 \mathrm{Cal} .548,169$ Pac. 80 (1917). In California it was not required that the object which allured the child must be the one that injured him. Faylor v. Great Eastern Quicksilver Mining Co., 45 Cal. App. 194, 187 Pac. 101 (1919). This was a requirement in other jurisdictions. United Zinc \& Chem. Co. v. Britt, 258 U.S. 268 (1921). Missouri today apphies an even stricter requirement, demanding an inherently dangerous condition as well as allurement. Patterson v. Gibson, 287 S.W.2d 853 (Mo. 1956).

88 CAIIF. L. REv. 266, 269.

9 "The applicability of the doctrine involves the elements of Iure to children . . .". Lopez v. Capitol Co., 141 Cal. App. 2d 60, 66, 296 P.2d 63, 65 (1956).

10 Edler v. Sepulveda Park Apartments, 141 Cal. App. 2d 675, 297 P.2d 508 (1956); Copfer v. Golden, 135 Cal. App. 2d 623, 288 P.2d 90 (1955); 41 CaIIF. L. Rev. 138 (1953). 
Another basis of liability rested wholly on the ground of an exception to the normal trespasser-licensee rule of no liability for neghigent injuries to trespassers and licensees. ${ }^{11}$ Liability was predicated on finding a condition which was:

artificial and uncommon, as well as dangerous, and capable of being rendered safe with ease without destroying its usefulness, and of such a nature as to virtually constitute a trap into which children would be led on account of their ignorance and inexperience. 12

The substance of this rule appears occasionally in recent California cases, ${ }_{2}^{13}$ including some which, in the alternative, rely on the more inodern doctrine set forth in the Restatement of Torts, section $339 .{ }^{14}$ Since it rests on a narrower basis of liability than the Restatement rule, continued reference to it presents a serious obstacle to the latter's complete adoption in California. ${ }^{15}$

Of late, however, the district courts of appeal have tended to base recovery on a broader negligence principle, ${ }^{16}$ which finds expression in the Restatement of Torts, section $339:^{17}$

A possessor of land is subject to liability for bodily harm to young children trespassing thereon caused by a structure or other artificial condition which he inaintains upon the land, if

(a) the place where the condition is maintained is one upon which the possessor knows or should know that such children are likely to trespass, and

(b) the condition is one of which the possessor knows or should know and which he realizes or should realize as involving an unreasonable risk of death or serious bodily harm to such children, and

(c) the children because of their youth do not discover the condition or realize the

11 Peters v. Bowman, 115 Cal. 345, 47 Pac. 113 (1896). The exception in favor of children is analogous to, but broader than, the trap doctrine under which the landowner may be liable even to adult trespassers for conduct in wanton disregard of their safety. See Loftus v. Dehail, 133 Cal. 214, 65 Pac. 379 (1901), explaining that on the facts of Malloy v. Hibernia Sav. \& Loan Soc., 3 Cal. Unrep. 76, 21 Pac. 525 (1889), even an adult could have recovered because the dangerous condition was an unguarded cesspool the surface of which was covered with a layer of deceptive earth to the level of the surrounding land. For a discussion of the trap doctrine in California see 41 Carrr. L. Rev. 138 (1953).

12 Morse v. Douglas, 107 Cal. App. 196, 201, 290 Pac. 465, 467 (1930).

13 E.g., Ward v. Oakley Co., 125 Cal. App. 2d 840, 271 P.2d 536 (1954); Walker v. Pacific Elec. Ry., 66 Cal. App. 2d 290, 152 P.2d 226 (1944).

14 Reynolds v. Willson, 149 A.C.A. 250, 308 P.2d 464, hearing granted May 15, 1957 ; Long v. Standard Oil Co., 92 Cal. App. 2d 455, 207 P.2d 837 (1949).

15 The narrower basis of hability under the trespasser-hicensee exception results from the fact that the court itself often determines whether the condition is uncommon and whether it constitutes a trap. The following statement is typical: "[W]e think it thoroughly settled ... that a pond of water, whether natural or artificial, is not to be included in the same class with turntables ... the inherent dangers of which are not obvious to a child." Polk v. Laurel Hill Cemetery Ass'n, 37 Cal. App. 624, 634, 174 Pac. 414, 416 (1918). (Emphasis added.)

16 Garcia v. Soogian, 156 A.C.A. 696, 319 P.2d 742, hearing granted, March 6, 1958; Large v. Williams, 154 Cal. App. 2d 315, 315 P.2d 919 (1957) ; Woods v. City \& County of San Francisco, 148 Cal. App. 2d 958, 307 P.2d 698 (1957); Edler v. Sepulveda Park Apartments, 141 Cal. App. 2d 657, 297 P.2d 508 (1956); Copfer v. Golden, 135 Cal. App.2d 623, 288 P.2d 90 (1955); Marino v. Valenti, $118 \mathrm{Cal}$. App. 2d 830, 259 P.2d 84 (1953); Long v. Standard Oil Co., 92 Cal. App. 2d 455, 207 P.2d 837 (1949). In Copfer v. Golden, supra, reference was made to CAL. CIv. CODE $\$ 1714$ which provides: "Everyone is responsible, not only for the result of his willful acts, but also for an mjury occasioned to another by his want of ordinary care or skill in the management of his property or person, except so far as the latter has, willfully or by want of ordinary care, brought the injury upon himself. The extent of liability in such cases is defined by the title on compensatory relief." (Emphasis added.)

17 Restatement, Torts $\$ 339$ (1934). 
risk involved in intermeddilng in it or in coming within the area made dangerous by it, and

(d) the utility to the possessor of maintaining the condition is slight as compared to the risk to young children involved therein.

Liability stems from the foreseeability of an unreasonable risk of harm to children; the social value of thus protecting children is deemed, as a matter of public policy, to outweigh the "right" of unrestricted free use of land. ${ }^{18}$ As pointed out in the comment on clause (a) of section 339 it is not necessary that the children's presence be caused by the dangerous condition or that the occupier should know that the condition is likely to attract children; it is enough that he can foresee the likelihood of their presence. California courts, having eliminated the requirement of allurement, are in accord with this general rule. ${ }^{10}$ Foreseeability is determined from such factors as the presence of nearby housing projects, ${ }^{20}$ nearby playgrounds, ${ }^{21}$ past trespasses, ${ }^{22}$ or the ready accessibility of the condition. ${ }^{23} \mathrm{~A}$ trespass is, however, usually not foreseeable when the condition is normally inaccessible to children ${ }^{24}$ or can be reached only with great difficulty and ingenuity..$^{25}$ However, the fact that the danger is inside a building will not necessarily preclude biability. ${ }^{20}$

Clause (b) of the Restatement rule makes it clear that the possessor must not only foresee the trespass but he limself must maintain the condition on the land; ${ }^{27}$ it must be one which he knows or should know involves an unreasonable risk to cliildren because of their inattentiveness and immaturity. ${ }^{28}$ It is to be noted that section 339 is restricted to injuries caused by dangerous conditions. ${ }^{20}$ In this respect Califormia courts have espoused a doctrine that is broader in scope. They have recognized that there may be recovery in situations involving dangerous activities as well as dangerous conditions where the facts so warrant. ${ }^{30}$ They have

18 Copfer v. Golden, 135 Cal. App. 2 d 623, 288 P.2d 90 (1955) ; Prosser, Torts 440 (2d ed. 1955).

10 E.g., Bradley v. Thompson, 65 Cal. App. 226, 223 Pac. 572 (1924), and cases cited in note 16 supra.

20 Long v. Standard Oil Co., 92 Cal. App. 2d 455, 207 P.2d 837 (1949).

21 Brown v. Southern California Edison Co., 120 Cal. App. 102, 7 P.2d 770 (1932).

22 Anderson v. United States, 138 F. Supp. 332 (N.D. Cal. 1956); see also Katz v. Helbing, 205 Cal. 629, 271 Pac. 1062 (1928). But cf. King v. Simons Brick Co., 52 Cal. App. 2d 586, 126 P.2d 627 (1942).

23 Clark v. Pacific Gas \& Elec. Co., 118 Cal. App. 344, 5 P.2d 58 (1931); Morse v. Douglas, 107 Cal. App. 196, 290 Pac. 465 (1930).

24 Doyle v. Pacific Elec. Ry., 6 Cal.2d 550, 59 P.2d 93 (1936) ; Lopez v. Capitol Co., 141 Cal. App. 2d 60, 296 P.2d 63 (1956); Betts v. City \& County of San Francisco, 108 Cal. App. 2d 701, 239 P.2d 456 (1952).

25 Minter v. San Diego Consol. Gas \& Elec. Co., 180 Cal. 723, 182 Pac. 749 (1919).

28 Marino v. Valenti, 118 Cal. App. 2d 830, 259 P.2d 84 (1953).

27 Gallagher v. Frederick, $366 \mathrm{~Pa} .450,77$ A.2d 427 (1951). But cf. Simmel v. New Jersey Coop. Co., 136 A.2d 301 (N.J. 1957).

23 Bruce v. Housing Authority, 365 Pa. 571, 76 A.2d 400 (1950).

20 Restatement, Torts $\$ 336$ (1934) is not so restricted and provides: "A possessor of land who knows that another is trespassing thereon or from facts known to him should know or believe that another is or may be doing so, is subject to liability for bodily harm thereafter caused to the trespasser by the possessor's failure to carry on his activities upon the land with reasonable care for the trespasser's safety." Comment (d), however, provides: "a possessor of land is not required to take into account an actual probability that others may trespass upon his land and to conduct his activities in such a manner as not to be unduly dangerous to them if they do trespass ....".

30 Hernandez v. Santiago Orange Growers' Ass'n, 110 Cal. App. 229, 293 Pac. 875 (1930). 
also considered the issue of a landowner's liability to trespassing children in two cases involving animals. While recovery was denied in both cases on other groumds, the question of whether the "attractive nuisance" doctrine would apply in such a case lias been expressly left open. ${ }^{31}$

The Restatement rule applies only to accidents involving artificial conditions. There is, however, a possible argument that California courts would allow recovery for injuries due to some natural conditions if the other requirements of the doctrine were met, in spite of the language to the contrary in Peters v. Bowman.32 The statement that there is no liability for damage caused by natural conditions was dictum in that case ${ }^{33}$ and, although this statement has been repeated in other jurisdictions, ${ }^{34}$ the real basis of distmction appears to be whether the condition is understood to be dangerous by the child, and not whether it is natural or artificial. ${ }^{35}$ Since there is no specific holding involving a purely natural condition, ${ }^{36}$ it would appear possible for a child to recover in the case of a concealed natural danger. ${ }^{37}$

Whether the Restatement requirement of unreasonable risk of harm in clause (b) means anything more than a foreseeable risk is not clear, ${ }^{38}$ but in California

31 Whalen v. Streshley, 205 Cal. 78, 269 Pac. 928 (1928) ; Baugh v. Beatty, 91 Cal. App. 2 d 786,205 P.2d 671 (1949). "Whether the attractive nuisance doctrine could be extended so far as to include a caged animal it is not necessary for us to determine, since the doctrine is not applicable to the facts in the present case." Id. at 791, 205 P.2d at 674.

32115 Cal. 345, 47 Pac. 113 (1896), opinion on denial of rehearing, $115 \mathrm{Cal}$. 355, 47 Pac. 598 (1896). "As to common dangers existing in the order of nature, it is the duty of parents to guard and warn their children, and, failing to do so, they should not expect to hold others responsible for their own want of care". Id. at 356, 47 Pac. at 599. Accord: Atchison T. \& S.F. Ry. v. Powers, 205 Okla. 322, 243 P.2d 688 (1952); Meyer v. General Elec. Co., 46 Wash. 251, 280 P.2d 257 (1955).

33 See Reardon v. Spring Valley Water Co., 68 Cal. App. 13, 228 Pac. 406 (1924).

34 E.g., Charmichael v. Little Rock Housing Authority, 299 S.W.2d 198 (Ark. 1957) ; McGuire v. Carey, 366 Pa. 627, 79 A.2d 236 (1951).

35 Compare Polk v. Laurel Hill Cemetery Ass'n, 37 Cal. App. 624, 174 Pac. 414 (1918) with Sanchez v. East Contra Costa Irrigation Co., 205 Cal. 515, 271 Pac. 1060 (1928). See also dissenting opinion in Plotski v. Standard Oil Co., 228 Ind. 518, 522, 92 N.E.2d 632, 634 (1950); Banker v. McLaughlin, 146 Tex. 434, 208 S.W.2d 843 (1948).

${ }^{36}$ Mclendez v. City of Los Angeles, 8 Cal. 2d 741, 68 P.2d 971 (1937) and Beeson v. City of Los Angeles, 115 Cal. App. 122, 300 Pac. 993 (1931), although put on the basis of a lack of artificiality cannot be said to have involved natural conditions.

37 Cf. Faylor v. Great Eastern Quicksilver Mining Co., 45 Cal. App. 194, 187 Pac. 101 (1919), which involved the death of a child trespasser occasioned by his fall into an unprotected deep mine stope located in an unlighted and abandoned section of a mining tunnel. Liability was found; quaere whether the court would have reached a different result had the stope been a crevasse created by nature instead of by the landowner.

38 Most probably the unreasonableness of the risk is encompassed in the application of the whole of section 339. Thus, it becomes unreasonable because of the child's lack of appreciation [clause (c)], the landowner's knowledge of the danger [clause (b)], the uneven balance of utility [clause (d)], and the landowner's knowledge that the children will trespass [clause (a) ]. Therefore, the inherent nature of the danger should be immaterial wherever the Restatement is apphed. In Large v. Williams, $154 \mathrm{Cal}$. App. 2d 315, 315 P.2d 919 (1957), the court, in applying section 339 , used the phrase "inherently dangerous," but this was not the basis of decision, and the court apparently used it only in the sense of unreasonable risk within the broad scope of this section. 
the requirement is probably that the danger be foreseeable rather than inherent. ${ }^{30}$ Even ordinary or normally static objects such as a railroad pushcart, a tubular metal trailer, a glass panel, a wheeled tar vat, and a metal boiler frame have come within the "attractive nuisance" doctrine since the use to which meddling children can put them is foreseeably dangerous. ${ }^{40}$ In most areas the California courts have considered all the facts and circumstances of the case in determining the issue of liability rather than categorizing classes where liability will or will not be recognized. Thus, where it was once declared that there could never be liability for a house under construction, it has now been recognized that where the requirements of the Restatement are met hability may attach.11 Similarly, categorization, though considered, has been avoided in the case of common vehicles and moving trains. ${ }^{42}$ Similarly in electricity, machinery, and excavation cases recovery has been allowed or disallowed depending on the facts, either on the Restatement basis or on earlier rules of liability. $\$ 3$ The child trespasser exception, however, has not been applied where the danger is obvious, such as jumping from a moving train ${ }^{44}$

39 Cahill v. E.B. \& A.L. Stone \& Co., 153 Cal. 571 , 96 Pac. 84 (1908); Callahan v. Eel River \& E.R.R., 92 Cal. 89, 28 Pac. 104 (1891) ; Barrett v. Southern Pac. Co., 91 Cal. 296, 27 Pac. 666 (1891). But see Camp v. Peel, 33 Cal. App. 2d 612, 92 P.2d 428 (1939). Some jurisdictions require inherent danger and use this to control the jury and himit the doctrine. Petrak v. Cooke Contracting Co., 329 Mich. 564, 46 N.W.2d 574 (1951). Where there is no doctrine of recovery for child trespassers an exception is sometimes made in the case of inherent danger. Mayer $v$. Temple Properties, 307 N.Y. 559, 122 N.E.2d 909 (1954). But see Calore v. Domnitch, 5 Misc. 2d 895, 162 N.Y.S.2d 173 (1957).

40 Recovery upheld: Cahill v. E.B. \& A.L. Stone \& Co., 153 Cal. 571, 96 Pac. 84 (1908), distinguishing George v. Los Angeles Ry., 126 Cal. 357, 58 Pac. 819 (1899); Garcia v. Soogian, 156 A.C.A. 696, 319 P.2d 742, hearing granted, March 6, 1958; Large v. Willians, 154 Cal. App. 2d 315, 315 P.2d 919 (1957) ; Copfer v. Golden, 135 Cal. App. 2d 623, 288 P.2d 90 (1955); Morse v. Douglas, 107 Cal. App. 196, 290 Pac. 465 (1930). Recovery denied: Hunsche v. Southem Pac. Co., 62 F. Supp. 634 (N.D. Cal. 1945) (impracticability of prevention); Marsiglia v. Dozier, 161 Cal. 403, 119 Pac. 505 (1911) (proximate cause).

41 Woods v. City \& County of San Francisco, 148 Cal. App. 2d 958, 307 P. 2d 698 (1957), criticizing Puchta v. Rothman, 99 Cal. App. 2d 285, 221 P.2d 744 (1950).

42 Sandberg v. McGilvray-Raymond Granite Co., 66 Cal. App. 261, 226 Pac. 28 (1924); Skinner v. Knickrehm, $10 \mathrm{Cal}$. App. 596, 102 Pac. 947 (1909). A similar result was reached on the basis of res ipsa loquitur in Strother v. Adohr Creamery Co, 133 Cal. App. 405, 24 P.2d 365 (1933).

43 Electricity: Minter v. San Diego Consol. Gas \& Elec. Co., 180 Cal. 723, 182 Pac. 749 (1919) ; Pierce v. United Gas \& Elec. Co., 161 Cal. 176, 118 Pac. 700 (1911) ; Brown v. Southern California Edison Co., 120 Cal. App. 102, 7 P.2d 770 (1932) ; Clark v. Pacific Gas \& Elcc. Co., 118 Cal. App. 344, 5 P.2d 58 (1931). Machinery: Callahan v. Eel River \& E.R.R., 92 Cal. 89, 28 Pac. 104 (1891); Barrett v. Southern Pac. Co., 91 Cal. 296, 27 Pac. 666 (1891); Giddings v. Superior Oil Co., 106 Cal. App. 2d 607, 235 P.2d 843 (1951); Wcik v. Southern Pac. Co., 21 Cal. App. 711, 132 Pac. 775 (1913). Excavations: Loftus v. Dehail, 133 Cal. 214, 65 Pac. 379 (1901) ; Edler v. Sepulveda Park Apartments, 141 Cal. App. 2d 675, 297 P.2d 508 (1956); Faylor v. Great Eastern Quicksilver Mining Co., 45 Cal. App. 194, 187 Pac. 101 (1919). A peculiar application of the doctrine has been made in cases of dynamite caps found on the premises and carried off by the child who is later injured when they explode. Recovery has been upheld both under the Restatement and the exception to the trespasser-licensce rule. Marino v. Valenti, $118 \mathrm{Cal}$. App. 2d 830, 259 P.2d 84 (1953), distinguishing Nicolosi v. Clark, 169 Cal. 746, 147 Pac. 971 (1915); Bradley v. Thompson, 65 Cal. App. 226, 223 Pac. 572 (1924), and Hale v. Pacific Tel. \& Tel. Co., 42 Cal. App. 55, 183 Pac. 280 (1919). Recovery was also allowed in Lambert v. Western Pac. R.R., 135 Cal. App. 81, 26 P.2d 824 (1933) on the basis of mere technical trespass. However, it has been suggested that neither doctrine is needed and that the situation can be handled with ordinary negligence rules. 2 Harper aNd JAMES, TORTS 1459 (1956).

44 Walker v. Pacific Elec. Ry., 66 Cal. App. 2d 290, 152 P.2d 226 (1944). 
or falling from a height ${ }^{45}$ or where the object is normally harmless such as a ladder, ${ }^{46}$ lime putty, ${ }^{47}$ or a stable. ${ }^{48}$

Under clause (c) of the Restatement provision the child must in fact fail to appreciate the danger because he is too young to comprehend or fully appreciate the risk..$^{49}$ Several California district court of appeal decisions lave adhered to this rule, ${ }^{50}$ and older California decisions have similarly stressed the iunportance of the age factor. ${ }^{51}$ It has been recognized that while an older child could not recover, a younger child could do so on the same set of facts. ${ }^{52}$ Moreover, age considerations are influenced to a great extent by the type of danger encountered. The age limit is much higher for less obvious dangers such as electrity ${ }^{53}$ than it is for coinmonly understood hazards. ${ }^{54}$ The child trespasser exception has been stated to be one applying to young children with the uppermost limit at about sixteen years of age and with few cases allowing recovery above the age of twelve. ${ }^{55} \mathrm{Natu}-$ rally, where there is actual knowledge of the danger there is no recovery regardless of how young the child may be. ${ }^{56}$

The last clause of the Restatement rule weighs the utility of the condition against the risk to children. ${ }^{57}$ Cahfornia authorities are in accord either in expressly citing clause (d) of section $339^{58}$ or in stating that the condition must be capable of being rendered safe with ease without destroying its usefulness. ${ }^{59}$ Thus

45 Doyle v. Pacific Elec. Ry., 6 Cal. 2d 550, 59 P.2d 93 (1936) ; Severance v. Rose, 151 Cal. App. 2d 500, 311 P.2d 866 (1957); Lopez v. Capitol Co., 141 Cal. App. 2d 60, 296 P.2d 63 (1956); Saba v. Jacobs, 130 Cal. App. 2d 717, 279 P.2d 826 (1955).

46 Saba v. Jacobs, 130 Cal. App. 2d 717, 270 P.2d 826 (1955). See also Meagher v. Hirt, 232 Minn. 336, 45 N.W.2d 563 (1951). In California there is no liability for objects intended for use by children. Solomon v. Red River Lumber Co., 56 Cal. App. 742, 206 Pac. 498 (1922). 47 Camp v. Peel, 33 Cal. App. 2d 612, 92 P.2d 428 (1939); but cf. Katz v. Helbing, 205 Cal. 629, 271 Pac. 1062 (1928).

48 Gianinni v. Campodonico, 176 Cal. 548, 169 Pac. 80 (1917).

49 See Hoff v. Natural Ref. Prod. Co., 38 N.J. Super. 222, 118 A.2d 714 (1955) for a collection of cases covering the "borderline" ages of 13,14, and 15 years.

50 See cases cited in note 16 supra. (1924).

51 E.g., Sandberg v. McGilvray-Raymond Granite Co., 66 Cal. App. 261, 226 Pac. 28

62 Giddings v. Superior Oil Co., 106 Cal. App. 2d 607, 235 P.2d 843 (1951).

63 Pierce v. United Gas \& Elec. Co., 161 Cal. 176, 118 Pac. 700 (1911).

54 Lopez v. Capitol Co., 141 Cal. App. 2d 60, 296 P.2d 63 (1956).

65 Prosser, Torts 444 (2d ed. 1955). In California sixteen years of age appears to be altogether outside the scope of the rule. Whalen v. Streshley, $205 \mathrm{Cal}$. 78, 269 Pac. 928 (1928); Minter v. San Diego Consol. Gas \& Elec. Co., 180 Cal. 723, 182 Pac. 749 (1919).

56 Loftus v. Dehail, 133 Cal. 214, 65 Pac. 379 (1901); Hernandez v. Santiago Orange Growers' Ass'n, 110 Cal. App. 229, 293 Pac. 875 (1930). The effect of a warning as regards the child's knowledge is not clear. In other jurisdictions it has been stated that a warning can be overcome by the attraction of the object. Selby v. Tolbert, 56 N.M. 718, 249 P.2d 498 (1952), wherein the natural attractiveness of melted red taillights on a trailer was held to outweigh a warning by the parent. Although no California case so holds, sone decisions involving particularly attractive objects ignore the fact that the child was warned. E.g., Sandberg v. McGilvray-Raymond Granite Co., 66 Cal. App. 261, 226 Pac. 28 (1924), wherein recovery was upheld despite the testimony of the engineer of the train which ran over the child that he "had to get down and push them off," and that the child, "told me to go to hell and mind iny own business," Id. at 266, 226 Pac. at 30.

57 Nichols v. Consolidated Dairies, 125 Mont. 460, 239 P.2d 740 (1952). This is an important limitation on the scope of the doctrine. Dugan v. Pennsylvania R.R., 387 Pa. 25, 127 A.2d 343 (1956).

U8 See cases cited in note 16 supra.

59 See, e.g., cases cited in notes 12 and 13 supra. 
recovery has been denied where the dangerous condition was a furniture van moving slowly down a city street because the burden of making it safe was out of proportion to the risk. ${ }^{60}$ On the other hand where, on similar facts, the accident could have been avoided with slight burden hability has been found. ${ }^{01}$

On the question of what means of prevention must be taken, it is settled that a mere warning is not necessarily sufficient. Thus, in a case involving a partially constructed house it was stated that, "When the cases speak of guarding the dangerous contrivance, they are not speaking of a warning of 'danger' or a notice to 'keep out' but of something that will physically prevent children and others from going upon the prenises." 62 Furthermore, the physical means of prevention must be more than mere ineffectual attempts such as a low hanging rope guard on three sides of a concealed pool of water which is clearly not sufficient and in fact probably a source of danger in itself by serving to trip trespassers into the pool. ${ }^{03}$ The fact that the means taken are the customary precautions does not necessarily relieve the landowner. For instance the fact that railroads generally do not lock their turntables but merely fasten them is of no noment in determining whether it is negligence not to use a lock. ${ }^{64}$

It has been stated that the California rule on trespassing children is substantially in accord with the Restatement but that the courts have drawn lines of distinction. ${ }^{65}$ The outstanding distinction is the California position on child drownings. The leading case of Peters v. Bowman ${ }^{66}$ held that there was no liability for trespassing children who drowned in a body of water on defendant's land. ${ }^{67}$ On its facts the Peters case was undoubtedly correct since the child was eleven years old and went "rafting" on the pond against the express warning of his father. The decision, moreover, was followed by other cases where recovery was also properly denied because the child was either old enough to appreciate the risk, ${ }^{68}$ or the water constituted an open and obvious danger, ${ }^{60}$ or the trespass was not foreseeable. ${ }^{70}$ However, the reasons given for the broad rule laid down in the Peters caso are not applicable to every situation. The difficulty arises in the fact that while most children old enough to roam at large are capable of understanding the danger

60 Allred v. Pioneer Truck Co., 179 Cal. 315, 176 Pac. 445 (1918).

61 E.g., Skinner v. Knickrehm, 10 Cal. App. 596, 102 Pac. 947 (1909).

62 Puchta v. Rothman, 99 Cal. App. 2d 285, 289, 221 P.2d 744, 746 (1950).

63 Long v. Standard Oil Co., 92 Cal. App. 2d 455, 207 P.2d 837 (1949).

64 Callahan v. Eel River \& E.R.R., 92 Cal. 89, 28 Pac. 104 (1891).

65 Puchta v. Rothman, 99 Cal. App. 2d 285, 221 P.2d 744 (1950) ; Restatencent, Torts, Car. Anno. $\$ 339$ (1940).

66115 Cal. 345, 47 Pac. 113 (1896), opinion on denial of rehearing, 115 Cal. 355, 47 Pac. 598 (1896).

67 Other jurisdictions which follow older doctrines regarding child trespassers are in accord, e.g., Plotzki v. Standard Oil Co., 228 Ind. 518, 92 N.E.2d 632 (1950). Contra: Saxton v. Plunı Orchards, $215 \mathrm{La}$. 378, 40 So.2d 791 (1949). Kansas seems to be tending toward the Restatement view. Galleher v. City of Wichita, 179 Kan. 513, 296 P.2d 1062 (1956); Smith v. Evans, $178 \mathrm{Kan} .259,284$ P.2d 1065 (1955). For a general discussion of the Catifornia child drowning cases see 8 HAST. L.J. 300 (1957).

68 Melendez v. City of Los Angeles, 8 Cal. 2d 741, 68 P.2d 971 (1937); Demmer v. City of Eureka, 78 Cal. App. 2d 708, 178 P.2d 472 (1947) ; King v. Simons Brick Co., 52 Cal. App. 2d 586, 126 P.2d 627 (1942) ; Beeson v. City of Los Angeles, 115 Cal. App. 122, 300 Pac. 993 (1931).

69 Ward v. Oakley Co., 125 Cal. App. 2d 840, 271 P.2d 536 (1954); Reardon v. Spring Valley Water Co., 68 Cal. App. 13, 228 Pac. 406 (1924); Polk v. Laurel Hill Cemetery Ass'n, 37 Cal. App. 624, 174 Pac. 414 (1918).

70 Van Winkle v. City of King, 149 Cal. App. 2d 500, 308 P.2d 512 (1957); Betts v. City \& County of San Francisco, 108 Cal. App.2d 701, 239 P.2d 456 (1952). 
of water there are some who, because of their extreme youth, cannot possibly be expected to appreciate the risk. This is equally true of other common dangers in the community, such as fire or falling from a height. In the first place, though it is still stated that the responsibility of guarding the child from such common perils rests wholly upon the parents, ${ }^{71}$ it has been recognized that the landowner owes a duty to an unattended infant where the trespass is known or should be known and the danger is great. ${ }^{72}$ Therefore, it would seem to make little difference whether the danger is a common one in the order of nature as long as the occupier has knowledge or reasonably should have knowledge of the presence of children who because of their tender years will fail to recognize the peril. ${ }^{73}$ Secondly, the argument in Peters that ponds in general serve a useful purpose is made irrelevant by the very facts of that case, for the pond there was abandoned. Clause (d) of the Restatement rule, while taking into account the usefulness of the condition, does so in the context of each case, a test which seems eminently more desirable than categorization of ponds in general as useful. Lastly, the Peters case, in stressing the impracticability of preventing the trespass, suggested that ponds would have to be dramed if California were to recognize liability for child drowning. But it would appear that any kind of barrier sufficient to put the child on its guard would be enough. ${ }^{74}$ In other California decisions difficulties of prevention, though great, as in the case of houses under construction, ${ }^{75}$ have been overcome; therefore, it appears that the water rule of California gams no support from this argnment.

However, the stare decisis weight of these water decisions has resulted in the blind application of the rule even where its only justification is precedent. Thus recovery has been denied as a matter of law in a case involving the swimming pool drowning of a two and one-half year old child for the reason that all children are taken to understand the perils of water. ${ }^{76}$ This is a typical outgrowth of categorization and such harsh results must be expected where courts indulge in this practice. ${ }^{77}$ The application of the Restatement rule to water cases results in no recovery for older children, ${ }^{78}$ but where the landowner knows of the trespass of

71 Wilford v. Little, 144 Cal. App. 2d 477, 301 P.2d 282 (1956). "The presence of danger to an unattended infant is not necessarily a test of anything but the need of parental care." Id. at 482,301 P.2d at 286.

72 Prosser, Torts 440 (2d ed. 1955).

73 Anderson v. United States, 138 F. Supp. 332 (N.D. Cal. 1956) ; Moore v. North Chicago Refiners \& Smelters, 346 Ill. App. 530, 105 N.E.2d 553 (1952); Galleher v. City of Wichita, 179 Kan. 513, 296 P.2d 1062 (1956); Eaton v. R.B. George Inv., 152 Tex. 523, 260 S.W.2d 587 (1953). Accord, Missouri Pac. R.R. v. Lester, 219 Ark. 413, 242 S.W.2d 714 (1951); Wolfe v. Rehbein, 123 Conn. 110, 193 Atl. 608 (1937); Cockerhanı v. Vaughan, 82 So. 2d 890 (Fla. 1955); Mann v. Kentucky \& Ind. Terminal R.R., 290 S.W.2d 820 (Ky.App. 1955); Genovese v. New Orleans Pub. Serv, 45 So.2d 642 (La. App. 1950); Ford v. Blythe Bros. Co., 242 N.C. 347, 87 S.E.2d 879 (1955); Simmel v. New Jersey Coop. Co., 136 A.2d 301 (N.J.1957).

74 Betts v. City \& County of San Francisco, 108 Cal. App. 2d 701, 239 P.2d 456 (1952). Even so there does remain the possibility that a fence itself might result in liability. Diglio $v$. Jersey Cent. Power \& Light Co., 39 N.J. Super. 140, 120 A.2d 650 (1956). It seems incongruous that a child too young to understand the dangers of water would be put on guard by a fence. Therefore its presence or absence should only relate to whether the landowner has niet his burden of prevention. Accordingly, if there were a barrier it would have to be kept in repair.

75 See note 41 supra.

76 Lake v. Ferrer, 139 Cal. App. 2d 114, 293 P.2d 104 (1956). But see 26 IND. L.J. 266 (1951), wherein it was pointed out that simce more children are probably killed by drowning than by any other means except car accidents the inference is that ehildren are not aware of the danger of water.

77 See Laning v. C.R. Crim Bldg. Co., 259 Ala. 268, 66 So.2d 121 (1953).

78 Mellas v. Lowdermilk, 58 N.M. 363, 271 P.2d 399 (1954). 
very young children who cannot be expected to realize the danger of water he may be liable. ${ }^{79}$

In California the two situations where liability is recognized for child drowning are where the water contains a hidden danger in the nature of a trap, such as a concealed siphon, ${ }^{80}$ or is masked, such as a body of water so loeated and camouflaged by its color and composition as to appear part of the surrounding land.1 In the past the exception lias been rather circumscribed; it was held that concealed pitfalls in a body of water did not constitute traps because the existence of such pitfalls is a commonly known fact. ${ }^{22}$ Further it is settled in California that the presence of floating objects in the water does not cliange the rule. ${ }^{83}$ However, in some jurisdictions recognizing the trap exception more latitude is allowed, as in a Florida case where a gently sloping white sandy beach was leld to constitute a trap. ${ }^{84}$ There is, however, some indication that California courts may be relaxing their stringent view. The recent case of Reynolds $v$. Willson ${ }^{85}$ involved an accident in a half-filled swimmmg pool, the sides of which were slippery with algae and mud; this condition was held to be a trap and recovery was allowed. Such expansion of the trap exception seems warranted and may serve to mitigate somewhat the harshness of the water rule.

There is a possibility that recovery for child drowning might be allowed in some cases if section 24400 of the California Health and Safety Code were applied. ${ }^{86}$ The point has been raised so far in only one case ${ }^{87}$ but not there considered because the claim was barred by the statute of limitations. Short of such a statute, it is unlikely that the strict water rule of Peters v. Bowman will be altered.

The danger of the California position on water hazards is expansion into otler areas. In the recent case of Knight $v$. Kaiser Company 88 the court held as a matter of law that a complaint phrased in the language of the Restatement of Torts, section 339 failed to state a cause of action where a ten-year-old, trespassing on defendant's sandpile, was asphyxiated when it collapsed on him. ${ }^{80}$ The court, following the rule laid down in the long series of child drowning cases, categorically stated that a sandpile is per se not an "attractive nuisance"; the reasoning is the same as that of the water cases:

\footnotetext{
79 See cases cited in note 73 supra.

80 Sanchez v. East Contra Costa Irrigation Co., 205 Cal. 515, 271 Pac. 1060 (1928).

81 Long v. Standard Oil Co., 92 Cal. App. 2d 455, 207 P.2d 837 (1949).

82 Melendez v. City of Los Angeles, 8 Cal.2d 741, 68 P.2d 971 (1937); Beeson v. City of Los Angeles, 115 Cal. App. 122, 300 Pac. 993 (1931). Accord: Phipps v. Mitze, 116 Colo. 288, 180 P.2d 233 (1947) ; Plotzki v. Standard Oil Co., 228 Ind. 518, 92 N.E.2d 632 (1950). But sce Davies v. Land O'Lakes Racing Ass'n, 244 Minn. 248, 69 N.W.2d 642 (1955).

83 Deunmer v. City of Eureka, 78 Cal. App. 2d 708, 178 P.2d 472 (1947); Reardon v. Spring Valley Water Co., 68 Cal. App. 13, 228 Pac. 406 (1924).

84 Allen v. William P. McDonald Corp., 42 So. 2 d 706 (Fla. 1949).

85149 A.C.A. 250, 308 P.2d 464, hearing granted, May 15, 1957.

86 Cal. Health \& Safety Code $\$ 24400$ provides: "Every person owning land in fee simple or in possession thereof under lease or contract of sale who knowingly perinits the existence on the premises of any abandoned mining shaft, pit, well, septic tank, cesspool, or other abandoned excavation dangerous to persons legally on the premises, or to minors under the age of twelve years, who fails to cover or fence securely any such dangerous abandoned excavation and keep it so protected, is guilty of a misdemeanor."

87 Ward v. Oakley Co., 125 Cal. App. 2d 840, 271 P.2d 536 (1954).

8848 Cal. 2d 778, 312 P.2d 1089 (1957).

80 But cf. Peters v. City of Tampa, 115 Fla. 666, 155 So. 854 (1934), wherein defendant city was lield liable for the death of a 10-year-old caused by the cave-in of banks of a stream undermined by the city's construction work.
} 
Pools of water and sandpiles duplicate the work of nature and are not uncommon. ... The dangers connected with and inherent in a sandpile are obvious to everyone, even to a child old enough to be permitted by its parents to play unattended.90

Although the court in reaching its conclusion cites the Restatement of Torts, it would seem that the rule was misapplied. In the dissenting opinion joined in by two other justices, Justice Traynor points out that under the Restateinent standard the issue of liability would properly be for the jury and that, in ruling as a matter of law, the court was either adopting a special sandpile rule (as in the water cases) or taking judicial notice of facts outside the complaint. As was noted in an Illinois case involving a lumber pile accident:

The naming or labeling of a certain set of facts as being an 'attractive nuisance' case or a 'turntable case' has often led to undesirable conclusions. The inclination is then to find a stare decisis pigeon-hole or category. The difficulty in such a procedure is that too often the result of such a search is the reaching of irreconcilable conclusions. ... [T] he only proper basis for decision in such cases dealing with personal injuries to children are the customary rules of ordinary negligence cases. 91

In jurisdictions following the Restatement rule it is commonly leld that the existence of the four requirements upon which the landowner's liability rests are for the jury. ${ }^{92}$ This is subject to the usual reservation that if plaintiff has failed to make out a prima facie case or if reasonable men could not differ the question will then be one of law for the court. ${ }^{93}$ Where Califormia courts have followed the Restatement this practice has usually been observed..$^{2 \pm}$ Indeed, the language of the Restatement has been specifically recommended as suitable for instructions to the jury both in California ${ }^{95}$ and elsewhere. ${ }^{96}$ Moreover, long before California courts began to apply section 339 the applicability of older doctrines covering trespassing children were similarly lield to be for the jury. ${ }^{97}$ However where water has been involved, some courts, while purporting to adopt the Restatement test, have ruled on its applicability as a matter of law. ${ }^{98}$ Other jurisdictions reaching

$9048 \mathrm{Cal} .2 \mathrm{~d}$ at 782, 312 P.2d at 1091. An Indiana case involving a sandpile, Anderson v. Reith-Riley Const. Co., 112 Ind. App. 170, 44 N.E.2d 184 (1942), cited by the majority, supports its position; however, the Indiana court did not purport to apply section 339 in reaching its result as did the majority in the Knight case. The other cave-in cases denying recovery which were rehed on by the inajority may, as the dissent pointed out, be explamed on their particular facts. Zager v. Union Pac. R.R., 113 Kan. 240, 214 Pac. 107 (1923) (age of child); Puckett v. City of Louisville, $273 \mathrm{Ky} .349,116$ S.W.2d 627 (1938) (trespass not foreseeable). Further, as also was noted by the dissent, there is considerable authority contrary to the majority position. Holmberg v. City of Chicago, 244 Ill. App. 505 (1927); Hawley v. City of Atlantic, 92 Iowa 172, 60 N.W. 519 (1894) ; Baxter v. Park, 48 S.D. 506, 205 N.W. 74 (1925); see also Gimmestad v. Rose Bros. Co., 194 Minn. 531, 261 N.W. 194 (1935) (lumber pile); Hoff v. Natural Ref. Prod. Co., 38 N.J. Super. 222, 118 A.2d 714 (1955) (refuse pile). Quaere: By analogy to the $K n i g h t$ case might not excavations be considered outside the scope of the doctrine since natural depressions in the ground are not uncommon?

$01 \mathrm{Kahn}$ v. James Burton Co., 5 Ill. 614, 126 N.E.2d 836, 841 (1955).

92 Beaston v. James Julian Co., 49 Del. 521,120 A.2d 317 (1956) ; Kahn v. James Burton Co., 5 Ill.2d 614, 126 N.E.2d 836 (1955) ; Patterson v. Palley Mfg. Co., 360 Pa. 259, 61 A.2d 861 (1948) ; Banker v. McLaughlin, 146 Tex. 434, 208 S.W.2d 843 (1948) ; Nechodomu v. Lindstroin, 273 Wis. 313,77 N.W.2d 707 (1956).

93 Guelda v. Hays \& Nicoulin Inc., 267 S.W.2d 935 (Ky. 1954); Jennings v. Glen Alden Coal Co., 369 Pa. 532, 87 A.2d 206 (1952).

94 See cases cited in note 16 suspra.

85 Long v. Standard Oil Co., 92 Cal. App. $2 d$ 455, 207 P.2d 837 (1949).

98 Eaton v. R.B. George Investments, 152 Tex. 523, 260 S.W.2d 587 (1953).

07 E.g., Pierce v. United Gas \& Elec. Co., 161 Cal. 176, 118 Pac. 700 (1911); Barrett v.

Southern Pac. Co., 91 Cal. 296, 27 Pac. 666 (1891).

98 Wilford v. Iittle, 144 Cal. App. 2d 477, 301 P.2d 282 (1956). 
a contrary result on almost identical facts make it clear that such a procedure is a misapplication of section 339.90 This exclusion of water from the normal rules as to judge and jury functions is a stare decisis hangover from the older cases which based recovery on the "attractive nuisance" doctrine. ${ }^{100}$ However, as was pointed out by the dissent in the Knight case:

There are no established precedents in this state dealing with sandpiles, as there are with respect to bodies of water, that might, under the doctrine of stare decisis, justify adhering to a rigid rule without regard to the facts of the particular case. 101

Since the majority cited the Restatement with apparent approval one would be led to believe that California has abandoned older doctrines of liability and is attempting to apply general neghigence primciples in the area of trespassing children. However, the court, in extending the water exception to sandpiles, stated that, "Where the facts are undisputed, as in the instant case, it is a question of law whether or not the facts alleged fall within the scope of the 'attractive nuisance' doctrine." ${ }^{102}$ The cases cited by the court as establishing this proposition did not involve water and so could not rest on it as an exception, and furthermore, they were all older cases, decided before the birth of section $339 .{ }^{103}$ When viewed in light of these facts this statement of the court may mean that California, rather than misapplying the Restatement, is actually moving away from it and espousing the older trespasser-licensee exception. Under this latter theory the court is in a strong position to control the jury, since the court itself may decide whether the condition is uncommon and dangerous and by this means may establish categories of duty. Moreover, in failing to recognize that from undisputed facts conflicting inferences can be drawn, ${ }^{104}$ the court may have effectively overruled the more liberal application of the Restatement by the district courts of appeal in cases involving conditions other than water. ${ }^{105}$ Thus, from a position of accepting the Restatement with modification, California may have moved to one of rejecting it. But even if the Knight case may be taken as merely misapplying section 339 in an isolated area it still cannot be said that this state substantially follows the Restatement, for the essence of the doctrine rests in general negligence principles and any categorization, even if restricted to sandpiles and water, amounts to prescribing fixed standards of recovery in a way that is being progressively abandoned in accident law. ${ }^{108}$

William John Martin, Jr.

99 Beaston v. Jaines Julian Co, 49 Del. 521, 120 A.2d 317 (1956). "It is for the trier of fact to decide whether the pit of water in this case constituted a condition involving an unreasonable risk of death or serious bodily harm' within the various facets of the rule expressed in Restatement section 339". 120 A.2d at 320.

100 Peters v. Bowman, 115 Cal. 345, 47 Pac. 113 (1896). Under the older rule the question of whether the condition created an attractive nuisance was for the court to decide as a matter of law. Noel, The Attractive Nuisance Doctrine in Tennessee, 21 TENN. L. REv. 658, 667 (1951). $10148 \mathrm{Cal} .2 \mathrm{~d}$ at 789,312 P.2d at 1096.

10248 Cal. 2d at 781, 312 P.2d at 1091.

103 Nicolosi v. Clark, 169 Cal. 746, 147 Pac. 971 (1915); Loftus v. Dehail, 133 Cal. 214, 65 Pac. 379 (1901) ; Hernandez v. Santiago Orange Growers' Ass'n, 110 Cal. App. 229, 293 Pac. 875 (1930).

104 Mah See v. North Am. Acc. Ins. Co., 190 Cal. 421, 213 Pac. 42 (1923); Spoltcr v. Four-Wheel Brake Serv. Co., 99 Cal. App.2d 690, 222 P.2d 307 (1950).

105 See cases cited in note 16 supra. But see Large v. Williams, 154 Cal. App. 2d 315, 315 P.2d 919 (1957), decided subsequent to the $K n$ ight case, wherein section 339 was applied as an alternative ground of decision in allowing recovery for injurics sustained by reason of the toppling of a boiler frane.

1062 HaRPER AND JaMTES, Torts 1457 (1956). 